\title{
Water Bodies in Besserman Mythology and Rituals
}

\author{
Elena Popova \\ e-mail: elvpopova@yandex.ru
}

\begin{abstract}
Springs and rivers determine the formation of the sacral landscape of settlements and play a part in the rituals, mythology, traditional world model and space of the Besserman. They serve as essential resources of subsistence, are used domestically and are taken into account when zoning settlements. Besserman villages are located on hills near rivers and large freshwater springs. In the traditional world model, rivers connect different parts of the space, i.e. the upper and lower worlds, upper and lower reaches, sky and earth. Rivers simultaneously serve as natural and mythological borders, functioning as roads both metaphorically and literally. According to popular belief, water from rivers and springs travels to the sky via rainbows, and then falls to earth and into rivers by way of rain and snow. Historically prayers were said and rituals held near rivers from the start of the floating of the ice to the autumn. In summer, they were held only in emergency cases (drought or wet summers). Water from springs had healing properties and was used in folk medicine. Alongside traditional perceptions, the Besserman also have local rituals related to the veneration of springs that are connected with Orthodox and Muslim beliefs and revered saints.
\end{abstract}

Keywords: Besserman, folk calendar, mythology, rituals, river, sacral landscape, spring 
The veneration of rivers and springs in one's locality is a constituent part of traditional and modern Besserman rituals: it is ingrained in the structure of the folk calendar and in rituals of seasonal field work. Rituals near rivers or springs are held in emergency situations, in certain seasons (i.e. when rivers were frozen) or during the floating of the ice. A large number of prayer sites are located near rivers and village springs. This special attitude to springs and rivers can be attributed to their domestic significance and the role they play in rural landscape and mythological concepts.

The materials presented in this article were collected during field studies in Besserman villages in north-west Udmurtia. Some comparative examples are also provided from expeditions to neighbouring peoples and, in particular, to the northern Udmurt and Cheptsa Tatar, who, like the Besserman, inhabit the basin of the Cheptsa River and its tributaries. Special attention has been paid to springs and rivers in modern rituals.

\section{The significance of springs and rivers to households and in settlement zoning}

Rivers and sources of drinking water are essential resources for subsistence. When selecting a location to build a village, the proximity of a river and springs was of key importance, alongside other natural resources, such as forests, good soil and availability of game. Springs play an important part in Besserman legends, while a river is mentioned as the road by which the first inhabitants arrived:

The first to arrive here was a Besserman called Kat'arin [who was descended from] Vorcha. He built a house on the hillside near the river. It is right where Vasily [who is descended from] Ol'oksana's house stands now. I guess he chose this place because of its proximity to water. Then other people 
started coming here with their families. This is how the settlement formed. It was named Vorcha (Vortsa) after Kat'arin who was descended from Vorcha (Fedotov 1982: 127).

Our ancestors travelled up the Lekma River. The people of Zhuvam sailed up right where the bridge crosses the river today. And that's where they remained. This place is still called Vuzh Gurt, i.e. 'the old village'. Sometimes during the ploughing season the old logs still come to the surface over there (FWM, 1990'1).

Besserman villages are located on hills near rivers and large springs with drinking water. This determined the zoning of the villages, i.e. the location of houses and streets with regard to cardinal directions and the river. Household structures (such as smithies, mills, livestock shelters, wood chopping blocks and walkway boards for washing clothes) were also built near springs and rivers. River meadows were good pastures and provided abundant hay. Fish from the rivers was an essential part of the local diet. The inhabitants of villages located near rivers abundant in fish sold some of their catch to villages that were situated further from rivers (Satrapinskiy 1854: L. 27). Winter and summer fishing is an essential activity for country folk, as well as a pastime and a means to diversify food supplies, giving rise to traditional meals made from local fish.

Village springs would have a log structure at the water's exit point, and sometimes also a fence around the entire spring area. One or more wooden planks would run from the spring, with one large plank meant for watering cattle and washing clothes. Village springs, along with wells and modern standpipes, are still used as sources of drinking water. Rituals are held near village springs and folk mythology is linked to them, as well as spatial taboos and preferences, in spite of a number of modern means for delivering water to houses. Water for ritual purposes is drawn directly from the springs rather than from tap, well or standpipe. 
The notions 'spring', 'well' and 'spring-well' can be expressed in Besserman as oshmes and vudor. The main village spring is referred to as z'eg vudor or 'large spring', while other springs, usually located outside the village, are oshmes. Springs often have special names, such as pichi oshmes 'small spring'; they also may be named after the people who found them, for example Pedod vudor 'Fedot's spring' (Gordino village), Savapi oshmes 'Savva's ancestors' spring' (Zhuvam village), and Kuz'ma oshmes 'Kuz'ma's spring' (Mitroshata village). Or they are named after the owner of the house that is closest to the spring. Springs near sacred groves were called 'springs near the place where people pray' (for example Zhuvam village). It was forbidden to desecrate springs or to muddy the waters in them. The points from which the spring flows are called oshmes sin' or the 'eye of the spring' and are regarded as sacral spring centres. When a spring is addressed in prayer the 'eye of the spring' is referred to.

According to popular belief, special rituals can help to increase the amount and height of water:

It is a small spring. A bull-calf should be killed next to it so that the spring is larger and comes in useful for eating and drinking. People would eat and drink [cook] from it (FWM, 2001²).

Springs were referred to in human terms, for example if a spring ran dry 'the spring dies' oshmes kuliz, while the emergence of a new spring was described as 'the spring that was born' oshmes vorz'ekiz. Desecration of a spring could lead to it drying out, especially if done on purpose, for example if the eye of the spring had ashes poured into it. There is a story about this in the legends of a village that was set up near a spring and later abandoned because it had run dry:

There are plenty of springs here. There used to be a spring in Kuki, which is a field near the village. The Pal'l'anpi (Pal'l'anpios) clan moved there at some point. They settled 
down there. That spring was little, and they say that somebody wanted to harm them and poured ashes into the spring, which closed the eye of the spring. Yes, such things would happen from time to time. They ran out of water. And you can't survive without water. The only way out is to dig a well. But there are few wells here, because the water runs very deep in the ground (FWM, 2009 ${ }^{3}$ ).

Bridges were built across rivers and there were boat crossings, and in shallow places people would wade or walk on logs or felled trees. Local rivers often served as natural borders between settlements or the territories of other villages and communities, in addition to which they were also regarded as mythological boundaries. Villagers would not buy livestock or poultry "from across the river" or transport animals across since it was believed that such livestock would not breed or survive in the new village. Before heading off on a long journey, or when the young men were sent to the army, or during wedding ceremonies, river crossings and bridges on routes out of the village were used for rituals of veneration for the rivers and the spirit-masters of the water. For example, wedding guests would dance and sing on a bridge and when crossing the river threw coins into the water, marking the border and buying the right to cross it (Yunda village, Balezino district). As part of the ritual marking conscription into the army, a recruit would throw a coin into the water over his shoulder when crossing the bridge, asking the River Master for a good journey. When a person crossed the river for the first time after the spring flood, he made offerings to the river and the River Master in the form of coins or bread. Such ways of marking the river and its crossing as a natural and mythological boundary existed within different rituals, cultures and road mythologies.

The locations for prayers and setting up ceremonial objects were selected with due consideration for where the river was located and whether drinking water was available for sacral meals. Springs and rivers often served as essential constituents of a sacred site. 


\section{Beliefs about the Spirit/Master of the water vukuz'o}

The veneration of springs and rivers, and relevant rituals, were related to both the household and mythological functions of rivers and springs, and to beliefs about the spirit (deity) of water and rivers, i.e. vukuz'o/vumurt (lit: Master of the Water). The Besserman believed that his habitat was springs, rivers, wells and artificial water bodies (ponds). The first prayer gathering in the calendar year was held when the floating of the ice started and the river was 'waking up'. This period was regarded as the activity cycle of the River Master. Prayers stopped when the river froze up and "the River Master fell asleep".

According to popular belief, the Master of the Water could be seen or encountered near a spring on the banks of the river, especially at 'dangerous' times of the day and year (midday, midsummer) when he was "sitting", "taking a rest" or "combing his hair". He was different from people because he had "wet edges to his clothes". It was forbidden to go swimming at midday in summer: he "stepped out of the river", "was travelling to the market to do some shopping" or "could drag careless swimmers underwater". Today these rules are still observed, meaning that swimming, walking into the river or washing clothes in it, at midday in summer was banned.

In popular perception the Master of the Water is an old man with a beard and long hair. He usually wears white clothes (a shirt and a kaftan) and sometimes appears in the shape of a woman. Meeting him was seen as a foretoken, and people tried to avoid it:

I don't know what kind of clothes he wears. They say longhaired vumurt sits near the water. If someone sees him, then let them. Inmar [the supreme deity] will protect us (FWM, 19994); 
Vukuz'o, the Master of the Water... Sometimes he can be seen. The woman who told me this story has passed away already. ... Once, in the evening, after milking the cows, everyone went back to the village, but she headed to the river to wash [her clothes]. ... And she said that she saw something. ... There was a woman with knee-length hair on the opposite bank of the river. She had long, beautiful, pure white hair. She was sitting there and combing it. The woman didn't even start washing her clothes, and without saying a word or making any noise she returned to the village (FWM, 20005).

People never touched anything found by the river, for example combs or soap, because they believed that they belonged to the Master of the Water, and if you took them you might get sick, scared or injured, or you might drown.

Perceptions of the Master of the Water are related to the mythological perception of rivers and springs, which are polysemantic objects included in the structure of numerous rituals. Every village had a place where prayers to the water springs and the Master of the Water were said near a river or village spring. Either a goose or a duck was sacrificed: "A bird that swims is offered up as a sacrifice". This phenomenon is represented in the name of a prayer and in the sacral space: "a sacrifice to the Master of the Water", "offer up a sacrifice to the water", "kill for the water", "a place for saying a prayer with a goose" or "a place where a goose is killed". The ritual of worshipping the Master of the Water is the veneration of water springs in the area: "[The offering] is made near the river for the sake of veneration of all rivers" (FWM, 20096).

A special ritual devoted to the local spring and the Master of the Water was held in special cases, with an attempt to involve a newcomer to the village or their family. For example, after moving to the house of her groom, the bride demonstrated her veneration by offering bread and coins to the spring and the Master of the Water: 
On the third day after the wedding, a member of a wedding procession would come to the house of the newlyweds, with musicians, and then together they headed to the river or an ice hole, if it was winter. The bride would throw a piece of bread, some butter, and a copper coin into the water, saying in Besserman: "Lest the water should scare me, but wash me. And lest vumurt [the Master of the Water] should grab me" (Steinfeld 1894: 247).

Prayers were said for the Master of the Water to accept the bride as one of his own kind and not scare her away (Popova 1998: 142). The bride would give the water from the spring to the people waiting for her at the gates, then make tea and invite the guests to dinner. The tradition of fetching water and the bride worshipping the spring and water guardian deities also existed among other peoples inhabiting the area (Udmurts, Russians and Tatars) (Il'yin 1926: 59; Zorin 1981: 122-123; Belitser 1958: 308).

\section{Springs and rivers in rituals}

The veneration of rivers and the Master of the Water vukuz'o stands side by side with the veneration of the deities and spirits of wild nature. This veneration emphasises the ritual and household meaning of rivers and springs and their special status in different fields of family and village life. Exposure to the local spring and the veneration of the Master of the Water are constituents of rituals included in the agricultural calendar, prayers relating to the weather and rituals associated with folk healing practices.

In the mythology and in the traditional world model rivers and springs are linked to the sky, since they replenish the sky's moisture. It was believed that the ends (or end) of a rainbow were in a river or spring: "One of its ends was in the river, and the other was up in the sky" (FWM, 20007); "It really flows from one river 
into another" (FWM, 20008); "The rainbow stems from the very middle of the spring. And then it flows into the sky" (FWM, 20019). According to popular belief, water travels to the sky via the rainbow and then falls to earth and into rivers by way of rain and snow.

They call the rainbow vuyuis' (lit: 'water drinker'). It appears after rain. They said that one of its ends dropped into the river to drink water. They called it a beautiful bow in our village. Look, there is a beautiful bow. It can be seen quite often when the rain passes. They used to say, "Look, it is drawing water from a river again" (FWM, 2000 $\left.{ }^{10}\right)$.

It is drawing water from the river for rain. Here comes the rainbow. They say it comes out to draw the water for the rain (FWM, 2000 ${ }^{11}$ ).

It was believed that with the help of prayers and by worshipping springs and rivers in dry weather or in the rainy months it was possible to ask for rain or fair weather. Balance in nature as well as precipitation were dependent on complying with spatial and temporal prohibitions that related to rivers and springs, especially in the period of the summer solstice, when it was forbidden to draw water using kitchenware, to swim or to wash clothes (especially of vibrant colours) near a spring or in the river. During the harvest and haymaking period putting a rake into the water was forbidden as it could cause bad weather, storms or even hurricanes:

This is what they used to do. When you go to wash clothes in the spring, no red or other brightly coloured clothes should be washed. Otherwise the weather could get windy. They used to have special watchmen in the village. They said that if it was windy, someone was washing clothes in the spring (FWM, 2001'2). 
At Gerber [during the summer solstice] washing clothes at lunchtime was not allowed, it had to be done between 3 and $4 \mathrm{pm}$. If this rule was broken, hail would beat down on the crops in the field (AFD, 2000 ${ }^{13}$ ).

When rye is ripening, washing clothes in the river is not allowed. The weather turns bad. There is thunder and lightning (FWM, 2000 ${ }^{14}$ ).

During the summer solstice drawing water from springs and rivers was allowed using birchbark or wooden kitchenware, but iron or dirty kitchenware, and making noise, were forbidden. Such prohibitions were common also among the Udmurt (Vladykina 1998: 84).

In the traditional Besserman world model, rivers connect different parts of a space, i.e. the upper and lower worlds, upper and lower reaches, sky and earth, and the elements of sacral space. The upper reaches of the river are endowed with positive features relating to wealth and prosperity, while the lower reaches are associated with the 'other' world and disease, while spring waters "take away misfortune and difficulties in life". Different rituals, prohibitions and rules of everyday life are related to these perceptions. For example, babies' clothes could not be washed in flowing water, in a spring, in the river or in an ice hole. This prohibition was related to the idea that one of the child's souls (urt) might slip into 'other' worlds along the river causing him or her to become ill (FWM, $1995^{15} ; 1993^{16}$ ). For the same reason washing a sick person's clothes in flowing water (either a spring or river) was forbidden.

The concepts of a river as a pathway between the worlds and of the upper reaches being part of some 'other' space often appear in rituals of purification as well as funeral and commemorative traditions. For example, in some villages, commemorative meals for a dead person and his or her ancestors were left outside the estate in the direction of the upper reaches of the river (Shamardan village). Diseases and insects (cockroaches and bedbugs) were sent off downriver: 
Sometimes we had bedbugs and fleas... We would send them off when the ice was floating. Before the ice started floating, we would put them into a box and take it to the river. We would ask them to drift away with the ice. But would they? They should be eradicated (FWM, 200177).

Just before the spring sowing, a special purification ritual was held on the riverbank. Villagers would walk around the village and knock on the door of every single house with wooden sticks, driving away diseases and evil spirits, and then walk down to the river. A tree trunk would be set up on the bank, and people would knock their sticks on it. They would also sing a tune called the arafa krez'(the arafa tune). Then they would throw the log and the wooden sticks into the river and send them away, singing a ritual tune (Popova 2004: 89). This is how diseases and the old year were sent away downriver, then the next day people would go into the field and start sowing, and the new agricultural year began.

The opposition of the upper and lower reaches of the river as different spaces also exists in the rituals of the Christmas cycle. According to folk belief, with the beginning of the Christmas period, from 6 January (Christmas Eve) the vozho spirits come from the upper reaches of the river, while at Epiphany they would head to its lower reaches. In this period, washing clothes in springs and rivers is forbidden, as is crossing the river, or even being near it, at night or during twilight. On the eve of the Epiphany, the farewell ceremony for Christmas spirits is held. The villagers see the Christmas spirits off along rivers with an accordion, porridge, bread and drinks, and say goodbye to them until the next year. Today, this ritual also incorporates a feast in the house and a procession heading beside the river, where porridge, bread and drinks are left on the bank or in an ice hole that has been dug in advance (Popova 2014: 105-110).

The folk calendar used to include separate rituals for the veneration of the river, the spring and the Master of the Water. When the floating of the ice started and the river was waking up, 
the ye kel'an/vu kel'an 'saying goodbye to ice/water' ritual was held. This marked a significant period in the agricultural calendar, i.e. the waking up not just of the river but of nature as a whole:

In spring, when the ice was breaking up, a householder, together with his family, and beer or home-made vodka, would come to the bank of the river, or a bridge, and pour a glass of beer or home-made vodka into the river, as if plying it with alcohol. While they were doing so, they kept asking the river for a safe floating of the ice, without doing any damage or taking anything away from anyone, i.e. without anyone in the family drowning during the summer. After that the villagers offered one another food and drinks, and young men and maids started dancing and singing (Satrapinskiy 1854: L. 30 ob.).

Villagers prayed and sang songs to the river and the Master of the Water, poured drinks into the water and threw bread and coins into it. A feast was held on the bank and people had fun, singing ritual 'ice farewell' songs, asking for prosperity, rain and good weather in summer from the river and the Master of the Water:

We had an ice farewell ceremony. We would go down to the river to say goodbye to the ice. We were standing near the river, making fires on the bank, singing different songs. We were throwing different things into the water for the Master of the Water vukuz'o; coins, for example. And nowadays as well, when we cross the river for the first time after the floating of the ice, we throw coins into the water. Otherwise he [the Master of the Water] might drag you down into the water (FWM, 1999 ${ }^{18}$ ).

We would come down to the river and sing the 'ice farewell' song on the river bank. We made fires.... We poured wine or home brew into the river. Just like before the start of sowing, 
we would put a cloth on the ground, sit around it and eat and drink. Then we would dance to the accordion. It was great fun. People would pour moonshine into the river downstream. Then we would bow to the river and ask it to take all of the bad things downstream and keep all of the good things. This was in spring, in April or maybe in May, after the snow had melted. No such feasts were held any later. People thought it was too late and that there was no use.... We would gather together near the water and sing songs. Yeah, we would sing songs, saying goodbye to the ice. We would sing songs and weep, all of us. This is how we said goodbye (FWM, 1999 ${ }^{19}$ ).

Words and actions had purifying properties: "Let the water take away all diseases" and "let us be healthy". People sought to determine the weather in the forthcoming summer using the condition of the ice: "If the ice was moving smoothly and concertedly", "we were saying goodbye to the ice, so that the weather in summer would be nice and the rain would fall in due time". Guns were fired in the direction of the upper reaches of the river so that there would be no severe thunderstorms or downpours in summer. The ice farewell ceremony was still being held as late as the second half of the $20^{\text {th }}$ century. It was quite common among the Udmurt, especially in villages near large rivers (Pervukhin 1888: 41; Vereshchagin 1998: 221-223; Minniyakhmetova 2000: 38-39). This ritual still survives in some settlements of the northern Udmurt and the Besserman that are near large rivers, such as the Cheptsa River and its tributaries. The tradition of coming to the river and observing the floating ice has significant emotional and aesthetic value.

Another important ritual in the peasant calendar of villagers is 'sacrificing a bull-calf with a prayer' also known as 'eating a bull-calf near the river', which took place in August and in which only men participated. The ritual, involving the slaughtering of a red bullcalf, was held near the river or near a village spring on 3 August, i.e. the day after Saint Eliyah's Day. 
On the day after Eliyah's Day, an offering was made to the Master of the Water. They would buy a red bull-calf and kill it on the bank of the river. Blood would be spilled on the ground. Women were not allowed to be there (Mashtakova 1970: L. 29-30).

Elijah's Day is a feast for the dead. They would once again kill a red bull-calf here, this time for vumurt [the Master of the Water]. They would kill a bull-calf near the river and pour its blood into the river (Biyanova 1946: L. 7).

Special prayers near the river in order to 'get the weather straight' were held in emergency situations, in summer droughts and in steady rain during the haymaking or harvest periods (FWM, 200120). In some villages, every householder held them annually, in turn, near the spring if there was nasty weather (Shutova 2004: 159).

The last ritual was held near the river in late October / early November, but before prayers were held in the sacred grove, which was the 'closing of the year', i.e. before 14 November (Cosma's and Damian's Day). People used to believe that when the river froze over, the Master of the Water took a well-deserved rest and fell asleep, and so no rituals were held after that. The last ritual was a family prayer session, with a bird (a goose or duck) being offered as a sacrifice to the river and the local spring and to the Master of the Water with gratitude for good weather and help in summer. People would also ask him for assistance in the future:

An offering was made by killing [an animal] near the river, for all of the rivers, and after that the ice 'closed down' (FWM, 2009²1);

Animals were killed as offerings to the water. People would [pray] near rivers. ... Almost all sacrifices were made in autumn. A goose was killed near the water so that there would be no problems when grazing cattle, for example they wouldn't drown. So that it would be sent off [to pasture] after 
a year, too, drink from the river and walk across it. This is what villagers would say, addressing the Master of the Water and the river: "Let there be a lot of bread. Let the cattle live long. Let us be happy and prosperous" (FWM, 199122);

Before Cosmas' Day, people tried to hold prayers with a goose. They killed a goose near the river, asking for an abundant goose flock. They boiled the goose near the spring. When collective farms were established, people started sacrificing geese [at home]. They would boil [and eat a goose] with their family members only, without any outsiders (FWM, 2000²3).

Every family would say prayers and hold a feast separately. The ritual was usually led by the head of the family or the oldest man in the family. Several adult men headed with him to the river, and sometimes boys, too. The autumn ritual included a bird offering, cooking ritual porridge and venerating of the river (or the spring):

Geese were killed near the river, so that goslings would not drown in the river. People would gather together and eat goose meat with their family members only. In more recent times they would cook meat at home, but bring feathers, bones, porridge and a hunk of bread to the river. They would leave them on the bank, near the river (FWM, 1995 ${ }^{24}$ );

If a goose was killed for vukuz'o ... they would take a goose to the river in the evening, kill it near the water and pour the bloodinto the water. Then they would boil the goose at home and throw the bones and everything else into the water (FWM, 198725).

A bird was gutted and butchered on the bank of the river, and porridge was cooked in the broth at that spot. In the second half of the $20^{\text {th }}$ century, this ritual was held secretly: a bird was killed near the river, but butchered and boiled at home, since it was 
forbidden to say prayers in public places. Ritual feasts were held in the house, but the feathers, bones, porridge and bread were taken to the river later. Outsiders were not allowed to take part in the feast, and parts of the sacrificial bird were not put into meals cooked on other days or given to outsiders.

The rituals for the Master of the Water and water springs stopped in winter. People would only come to the river to say farewell to the Christmas spirits vozho on the eve of Epiphany and when consecrating the Epiphany baptismal font in the local river.

\section{Water from springs and rivers in folk healing practices}

Water from springs, especially from the most important village spring, was imbued with healing properties. It was used to treat diseases and the evil eye, and was drunk to "be healthy" and "derive strength from the spring". People sought to transfer the qualitative attributes of a spring, such as power, energy and purity, onto human beings. The water drawn from several springs (in odd numbers as a rule, i.e. three, five or seven) was imbued with healing properties, thus intensifying them even more. Water drawn downstream, on any Thursday, or from three springs in the morning or during twilight was imbued with healing properties. An iron object was placed in the dish with the water, which was closed with a lid or a towel in an attempt to protect it from evil spirits. Slack water was regarded as being dead, in addition to which, water drawn upstream could cause disease, since disease was sent away downriver. 'Living' water could be drawn from flowing water running from the spring downstream. The quality of water could change in different parts of the day and the calendar. Villagers would try to draw water early in the morning or during twilight, i.e. during akshan, which was a sacral liminal period: 
Water is drawn from Thursday to Friday from three locations: a spring, a river and some other spring. This is akshan vu. They would wash children's faces with this water. Akshan means twilight, the sun at sunset. Elderly people would fetch water at akshan, too. Akshan vu is drawn in the evening, not in the morning. When things get really bad, healer women are invited. If a sick person was getting better, it was believed that the right word [magic spell] had been said (FWM, 1999²6).

People would go to fetch water in important temporal and calendar periods, on Holy Thursday and on the Epiphany. For example, Epiphany water was stored for healing for the whole year. 'New vil'vu water' fetched in the early morning on Holy Thursday was believed to have special properties:

The 'new vil' vu water' was fetched from the spring early in the morning on Holy Thursday. It was sprinkled on cattle and children and washed the faces of crying babies' (FWM, 1992 ${ }^{27}$ );

People still fetch water from the spring on Holy Thursday and at Epiphany. When they are fetching the water, they do not talk to anyone they meet on the way home. Then they sprinkle this water on cattle and wash their faces with it. Or drink it (FWM, 2000²8);

On Holy Thursday, they would put a silver coin in a bucket and go to the spring to fetch some water (FWM, 1993 ${ }^{29}$ ).

"People would wash their faces with fresh water from the river so as to be healthy for the whole year", - as the local priest described the ritual of the Bessermans and the Udmurts in the mid- $19^{\text {th }}$ century (Satrapinskiy 1845: $23 \mathrm{ob}$.). The 'new water' was stored for the whole year, away from doors and windows, under a bench in the kitchen cupboard, behind icons. 
Several rules were connected with springs: drinking from the spring or leaning into it was forbidden, rather the water was scooped up using a dish or the palm of one's hand. First of all, the spring had to be treated or fed by dropping a piece of bread, a coin, some grass or a leaf into it. "If you are drinking from the spring, drop some bread crumbs into it. Otherwise it will 'catch' you. Or, as they say today, diseases come from it" (FWM, 200030). As a rule, they would say: "Don't grab me!"

Some village springs were regarded as 'dangerous', i.e. l'ek oshmes 'an evil/dangerous spring'. They could 'catch' people, especially during liminal periods (midday and twilight). In such cases, people would bring food (grain or flour) or certain objects (wool, fabric or coins) to the spring:

We have a log padeyshur. A dangerous spring. We try not to draw water from there or go there. Disease 'catches' people. We made [offerings] to the master of that spring. ... Some people would still never set foot there. They say some people did and became sick. They got abscesses on their feet which 'watered' like the eye of the spring.. ... They say it was all because of the evil spring. ... The disease 'caught' them, their feet were 'watering', vesicating, or their arms were vesicating. And it was all because of 'setting foot' near that spring. They say it was all because of the spring. ... They said the disease was clinging to them. They say it's because of the spring. They turned to my mother, too. Made offerings to the master of the spring. But the disease 'caught' them. We made some [offerings], some food and drink [were offered]. We brought bread and butter to the spring. [We brought] grain (FWM, 2000 ${ }^{31}$ ).

Folk healing methods took due consideration of the different semantic specifications of the upper and lower reaches of the river, and slack and flowing water. Slack water was regarded as dangerous and 'dead'. For healing purposes, people were only 
allowed to take water downstream, not upstream, because they believed that if water was taken against the current, they might "scoop up a disease". Different objects were sent downriver (threads, sauna whisks, branches) as well as diseases. New whisks were thrown into the river after being used in the bathhouse on the eve of Kupala Night (7 July), because people believed that if you sent the whisk down the river it would take away all of your diseases (FWM, 1991 ${ }^{32}$ ). For the same purposes, threads collected on the morning of Holy Thursday were thrown into a river or spring:

Threads were tied up on the morning of Holy Thursday. Children would collect the threads. Then the threads were sent away down the river. Some people still do that. Different silk threads are tied together: yellow, green, blue and black (FWM, 2000 ${ }^{33}$ ).

If people believed that the the Master of the Water had caused a fright or a disease, they would bring bread or porridge to the river and hold a healing ritual on the bank. For example, if a child got scared near the river, or after falling into the river started stammering, they would turn to the Master of the Water near the river with a request not to scare the child anymore. Then they would feed the sick child with porridge oatmeal from a magpie's nest, trying to bring back his fluent speech (Turchino, Filimonovo, Istoshur villages).

\section{Veneration of springs in the context of Orthodox and Muslim traditions}

Within the context of the veneration of springs, in addition to traditional concepts there are also local rituals that take us back to the traditions of Islam or Orthodoxy. The emergence of such springs is usually related to a miraculous event or saint. Such springs turned into places of worship for people residing in other 
villages and pilgrims from faraway places, as well as being visited by representatives of other religions.

While researching the territory inhabited by the Besserman, two springs the veneration of which is related to Orthodox traditions were found. These are tumpal oshmes 'Tumpal spring' (Tumpal village, Yar District) and the Holy Spring (Kamennoye Zadel'ye village, Balezino District).

As recalled by locals, Tumpal spring is a "popular spring", "regarded as a praying and healing spring"; they also recall that "priests used to visit it". According to some legends, a number of miraculous healings took place here, and it helps "to get rid of different diseases". People visited this spring during wedding ceremonies and on memorial days, but mainly after the Trinity on Whit Monday, drawing water for healing, washing themselves and leaving coins in the spring (FWM, 2009 ${ }^{34}$ ). The locals believed that this spring acquired its special status when the parish church operated nearby. "The priest came to this spring and consecrated it with an icon of the Mother of God". Since then, it has been regarded as having healing properties and has been revered. People visited it on Whit Monday, which was a very important event in the parish. After the church was closed no prayer services were held, but the tradition of visiting the spring did not end, and people continued having feasts and making porridge near the spring. In the $1960^{\mathrm{s}}$ and $1970^{\mathrm{s}}$, the area around the spring was made more comfortable, and a table and bench were installed. People drew water from the spring, washed their faces and left coins. "People throw coins into it to be healthy" (FWM, 2009 ${ }^{35}$ ).

Another revered spring is the Holy Spring, which is a famous Orthodox sanctuary in Kamennoye Zadel'ye village. According to legend, its appearance was marked by a miracle, named after the reverend Tryphon of Vyatka (a miracle worker), a locally venerated saint of Kirov Oblast and Perm Oblast, the archimandrite, founder and senior priest of Vyatka Uspensky Trifonov Monastery in Khlynov (present-day Kirov) (Osokin 1912; Vyatka Eparchy 1912: 
527-528; Works of Vyatka Academic Archival Committee 1912: 24; Tryphon of Vyatka 1996: 447). Legends about Tryphon of Vyatka and the emergence of the spring were recorded in the late $19^{\text {th }}$ century, saying that the spring started flowing from the place where he took a stone:

They say that the reverend Tryphon was working at Kamennoye Zadel'ye (on the route between Polom and Balezino), where he was moving millstones. ... Once, on the banks of the Cheptsa River, Tryphon, after being laughed at by other workers, rolled the millstone down into the river, and this is when a miracle happened: the millstone did not sink, but was lying on the surface of the water, just like on solid ground. Tryphon sat on top of the millstone and travelled down the river (Vereshchagin 1886: 202).

Some peculiar features were attributed to this spring after the healing of a surveyor who strayed into the area by chance. The first cases described in the legend date back to the mid- and late $19^{\text {th }}$ century:

The veneration of this spring started recently, and this is what happened: a surveyor was passing by our village, and his eyes hurt. Due to some secret inclination, he approached the spring, leaned over it, washed his face with its water and a miracle happened: his illness left his eyes like dirt from his hands. People from neighbouring villages heard about this miracle, and sick people started visiting the spring with a strong belief in the miraculous power of the water; many of them were healed completely (Vereshchagin 1889: 5-6).

The spring was visited by people on Whit Monday, on important Orthodox and patronal days, when people were sick (especially by people with eye diseases) and by those who just came to pay respect to the sacred place (Osokin 1912: 51; AFD, 2004). The chapel of the 
Holy Spirit and the Dormition of the Mother of God were built near the Holy Spring. In 1913, a wooden church was built on the site of the chapel (Pravoslavnye khramy Udmurtii 2000: 137).

The traditional beliefs of the Bessermans and the Tatars were associated with the veneration of the spring zek oshmes, "a large spring" in the village of Gordino, inhabited by Orthodox Bessermans and Muslim Tatars. The spring is well-known far beyond the village, and it is believed that its water has healing properties.

There are a number of reasons for the veneration of the spring and its healing properties. According to one of the legends, it flows from beneath "a holy grave". There is a grave on the hill several hundred metres above the spring. According to legend, a Muslim saint was buried here. The site is especially revered by the Bessermans and Tatars inhabiting the village and Tatars from neighbouring villages and other locations throughout the Volga Region (Popova 2004; 2011: 244). A stone with an inscription in the Bulgar language was found on the site of the grave, which dated back to 1323 (Yusupov 1960: 20). The locals refer to this grave as auliya keber 'the holy grave', auliya 'the saint' and auliya Damrikhan 'Saint Damrihan'. The villagers believe that this burial site belongs to a 'holy' or 'respected' man, or to the first settlers. This is why the spring is also revered, since it is located right next to this holy place.

According to another legend, the spring emerged after the first settlers made a sacrifice, since there was no water in their new settlement:

When they came here, there was no water here at all. They were living here with no water. The first settler made an offering. They made kârban [sacrifice] ... and this is when the spring emerged. ... (FWM, 1999 $\left.{ }^{36}\right)$.

This spring is a source of drinking water which flows into the village through pipes. The revered burial site, the spring and the place for saying summer prayers form a single complex. There is a special sacral ground near the spring where Muslim Tatars and 
Orthodox Bessermans used to hold a summer ritual and pray for good weather. They slaughtered a sheep (bull) there. As before, village prayers are led by a mullah and the Tatar men who know the prayers and the ritual itself:

We eat a bull behind the village. This is our long-term tradition. We eat the bull praying for good weather. It is like a feast. We say prayers, too. We do it all together, Bessermans and Tatars (FWM, 1999 ${ }^{37}$ ).

We would hold this ritual whenever the weather turned bad, it was raining too much or not raining at all. If there was too much rain or hail or storms, then we would hold the ritual. And by Saturday everything would calm down (AFD, 2004 ${ }^{38}$ ).

The people from this village and from neighbouring villages came to the spring to draw healing water. When trying to figure out the reasons for a disease the healer women would pour tin into the water from the spring:

There is a large spring nearby, in a small ravine. It is a holy spring. People would come to the spring from different places. They would even bring dishes to draw the water from the spring. They would wash children's faces with it and pour it over them. It can cure you, like some sort of medication (FWM, 1999 ${ }^{39}$ ).

They would make offerings near the spring. Right nearby. It is the most important place. They don't even walk in its waters. It is a large spring. We drink water from it. So you can't spoil it. It will 'catch' you there (FWM, 2004 ${ }^{40}$ ).

If the reason for the disease was associated with the spring, offerings were left nearby, such as flour, grain and salt. At the summer solstice and until the end of summer, the Tatars and Bessermans tried not to 
bother the spring, neither drawing water from it nor washing clothes there. This requirement is still quite strict today. People who come to the village still draw water from the spring and take it home with them.

\section{Conclusion}

Rituals and mythological perceptions of rivers and springs are built on the basis of their essential domestic purpose and the place they occupy in the system of subsistence and the historical and cultural landscape. Within the framework of the cosmogonic model of the world, a river is at the same time a passage from one world into another and a spatial borderline. The road to the upper and lower reaches of the river and crossing the river are represented in the mythology of the road and in the relocation in space of both the souls of the dead and spirits, diseases, ritual participants, ordinary people and travellers. The concepts of upper/lower reaches of the river lie in the semantic field of such oppositions as up/down and determine the structure of rituals as well as the location of sacral objects.

Prayers and addresses to a river or spring are also held today, whenever the need arises. This tradition has been retained for a long time by the people working near the rivers (millers and shepherds) and was associated with bodies of water. The veneration of local rivers is obvious in everyday and festive culture, in rituals aimed at improving the weather and when addressing the springs in folk healing practices. The rituals still include perceptions of the purifying and healing properties of the water.

The veneration of rivers and of the spirit deity, the Master of the Water, and of cult practices as a whole, are linked to the traditional perceptions of nature, waters and precipitation included in the annual calendar cycle, and were part of cosmogonic perceptions. Information about the rituals held in the past is still preserved and handed down in the form of oral tradition and place names and is still alive in folk healing practices and ecological and landscape knowledge. 
Photo 1. Village spring and a block for washing clothes. Bessermans, Mitroshata village, Yukamenskiy District, Udmurtia. Photo: Elena Popova. 2009.

Photo 2. Village spring of drinking water. Blocks for drainage and washing clothes. Bessermans, Zhuvam village, Yukamenskiy District, Udmurtia. Photo: Elena Popova. 2009.
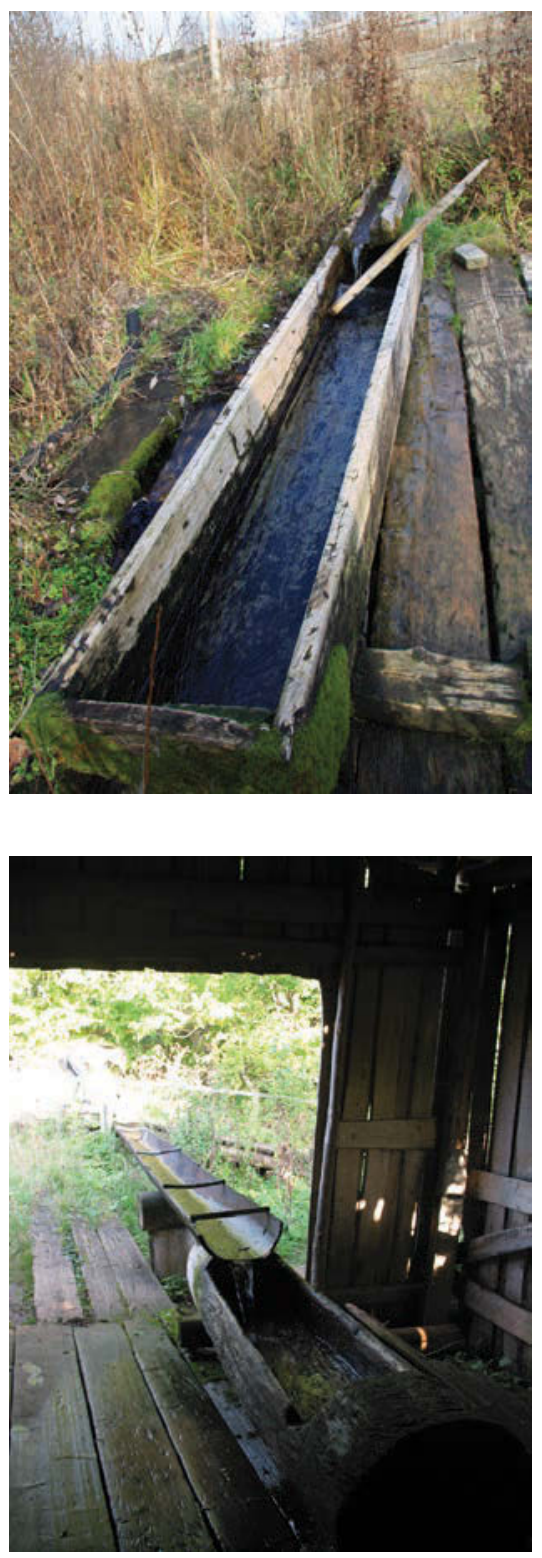


\section{Elena Popova}

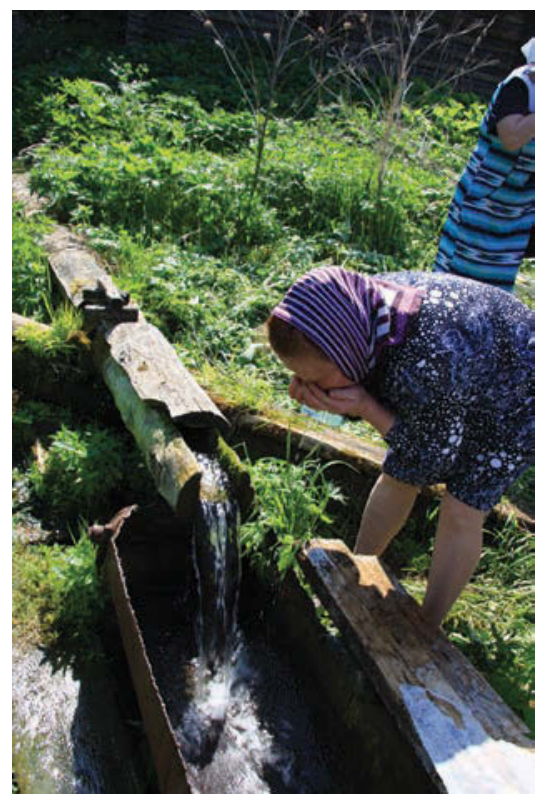

Photo 3. Revered village spring. Bessermans and Cheptsa Tatars. Gordino village, Balezino District, Udmurtia. Photo: Elena Popova. 2015.

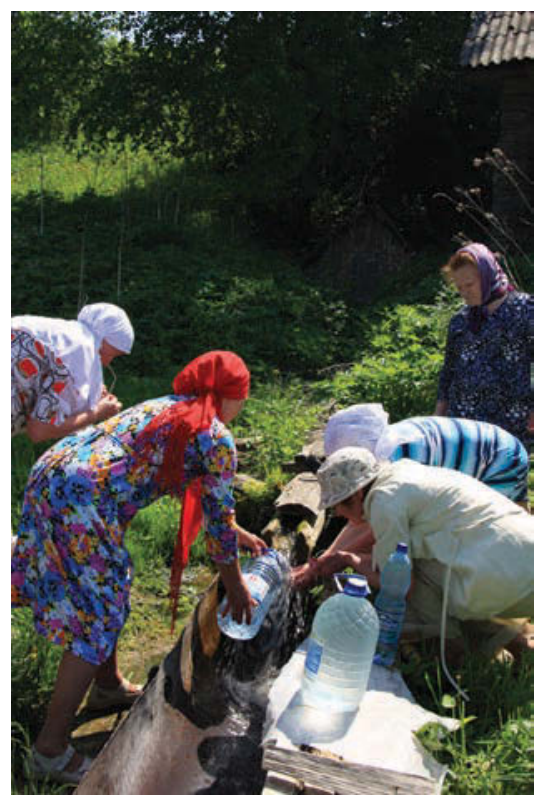

Photo 4. Participants in a village celebration and prayers, drawing water from the revered spring. Bessermans and Tatars, Gordino village, Balezino District, Udmurtia. Photo: Elena Popova. 2015. 


\section{Water Bodies in Besserman Mythology and Rituals}

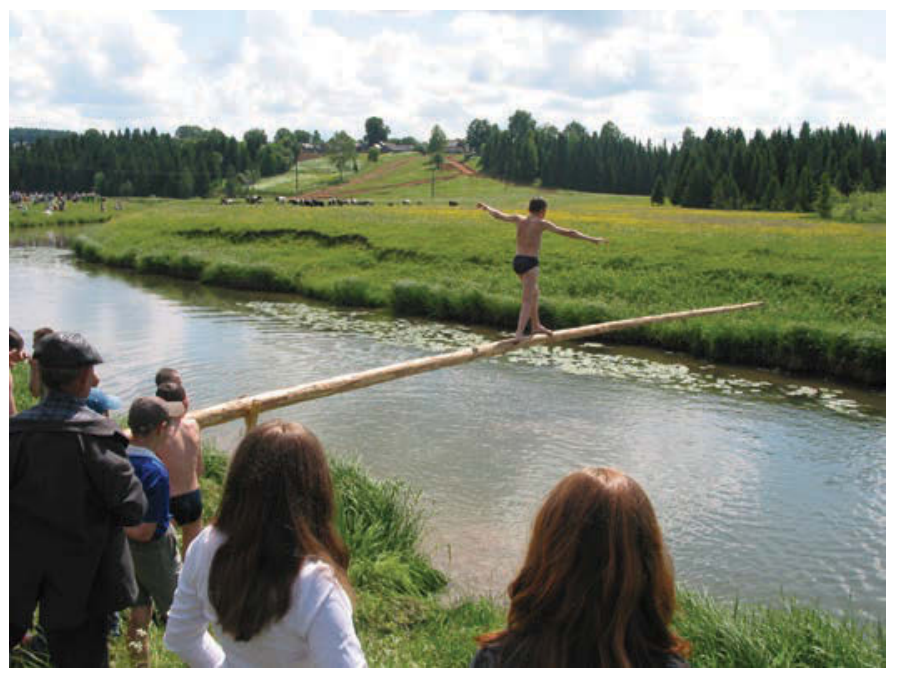

Photo 5. A contest in walking across a pole above the river. The feast day of the Besserman. Abashevo village, Yukamenskiy District, Udmurtia. Photo: Elena Popova. 2006.

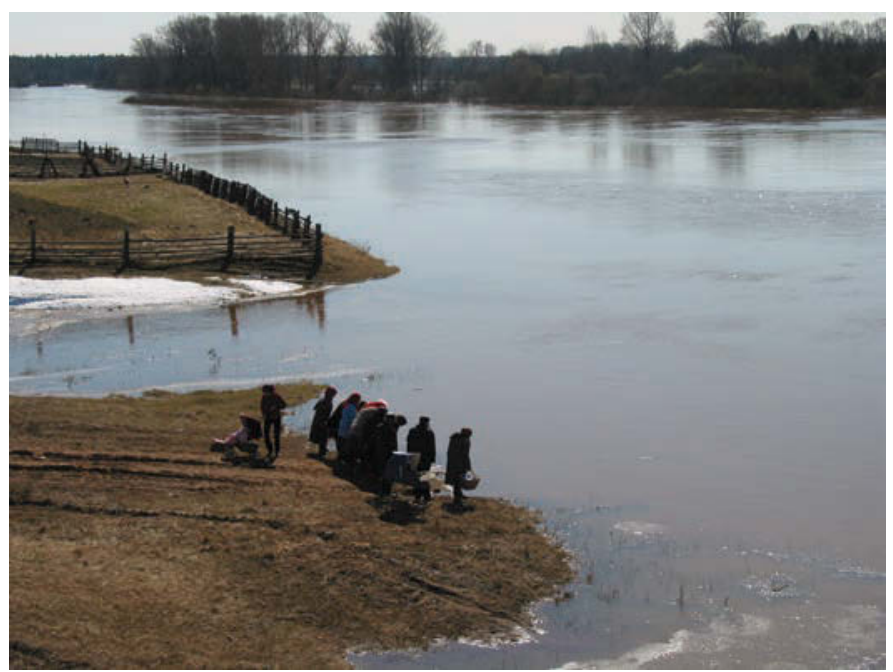

Photo 6. "Saying farewell to the ice" and prayers of the northern Udmurts on the Cheptsa River. Ozon village, Kez District, Udmurtia. Photo: Elena Popova. 2006. 


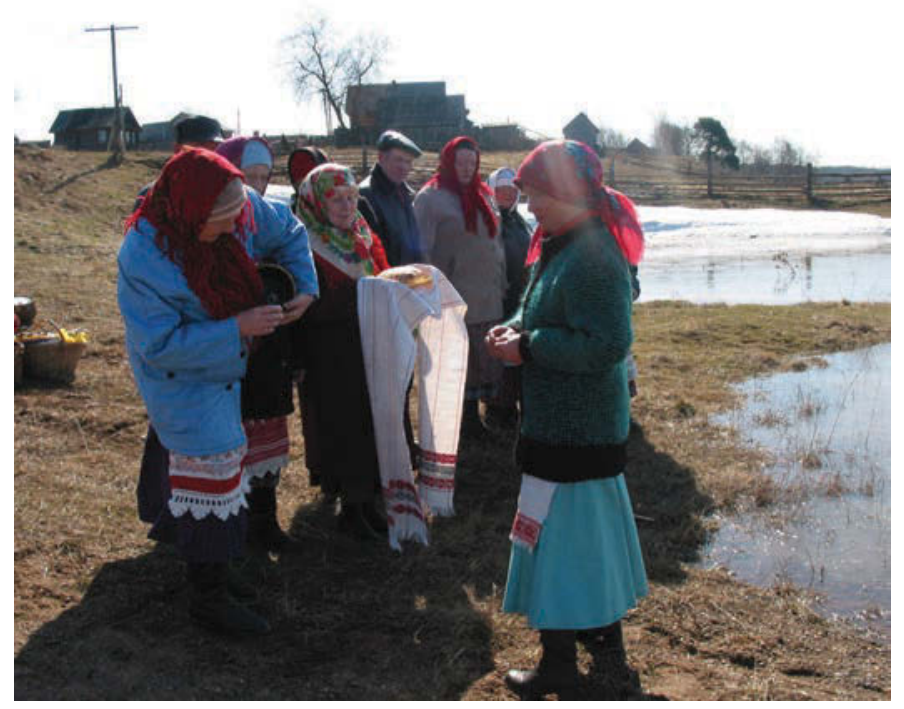

Photo 7. "Saying farewell to the ice" and visiting the river during spring prayers on the Cheptsa River. Northern Udmurts. Ozon village, Kez District, Udmurtia. Photo: Elena Popova. 2006.

\section{Notes}

1 Recorded from M. A. Nevostruyev, in Mitroshata village, Yukamenskiy District, Udmurtia, by Elena Popova.

${ }^{2}$ Recorded from I. K. Malykh, in Zhuvam village, Yukamenskiy District, Udmurtia.

${ }^{3}$ Recorded from N. A. Bekmement'yev, in Yozhevo village, Yukamenskiy District, Udmurtia.

${ }^{4}$ Recorded from M. A. Ponomareva, in Korotay village, Glazov District, Udmurtia, by Elena Popova.

5 Recorded from E. G. Zyambakhtina, in Turchno village, Yukamenskiy District, Udmurtia, by Elena Popova.

6 Recorded from K. A. Gavrilova, in Vortsa village, Yar District, Udmurtia, by Elena Popova. 
7 Recorded from E. G. Zyambakhtina, in Turchno village, Yukamenskiy District, Udmurtia, by Elena Popova.

${ }^{8}$ Recorded from M. V. Sabrekova, in Shamardan village, Yukamenskiy District, Udmurtia, by Elena Popova.

9 Recorded from I. K. Malykh, in Zhuvam village, Yukamenskiy District, Udmurtia, by Elena Popova.

${ }^{10}$ Recorded from V. N. Borisov, in Shamardan village, Yukamenskiy District, Udmurtia, by Elena Popova.

${ }^{11}$ Recorded from R. M. Karavayeva, in Shamardan village, Yukamenskiy District, Udmurtia, by Elena Popova.

${ }^{12}$ Recorded from I. K. Malykh, in Zhuvam village, Yukamenskiy District, Udmurtia, by Elena Popova.

${ }^{13}$ Recorded from D. A. Malykh, in Zhuvam village, Yukamenskiy District, Udmurtia, by Elena Popova.

${ }^{14}$ Recorded from M. V. Sabrekova, in Shamardan village, Yukamenskiy District, Udmurtia, by Elena Popova.

${ }^{15}$ Recorded from A. N. Baltacheva, Baltacheva Z. I., in Tylys village, Yukamenskiy District, Udmurtia, by Elena Popova.

${ }^{16}$ Recorded from I. K. Malykh, in Zhuvam village, Yukamenskiy District, Udmurtia, by Elena Popova.

${ }^{17}$ Recorded from L. A. Vershinina, in Zhuvam village, Yukamenskiy District, Udmurtia, by Elena Popova.

${ }^{18}$ Recorded in Gordino village, Balezino District, Udmurtia, by Elena Popova.

${ }^{19}$ Recorded from M. A Ponomareva., in Korotay village, Glazov District, Udmurtia, by Elena Popova.

${ }^{20}$ Recorded in Zhuvam village, Yukamenskoe District, Udmurtia, by Elena Popova.

${ }^{21}$ Recorded from K. A. Gavrilova, in Vortsa village, Yar District, Udmurtia, by Elena Popova.

${ }^{22}$ Recorded from E. G. Zyambakhtina, in Turchno village, Yukamenskiy District, Udmurtia, by Elena Popova.

${ }^{23}$ Recorded from T. S. Baltacheva, in Tylys village, Yukamenskiy District, Udmurtia, by Elena Popova. 


\section{Elena Popova}

${ }^{24}$ Recorded from E. G. Zyambakhtina, in Turchno village, Yukamenskiy District, Udmurtia, by Elena Popova.

${ }^{25}$ Recorded from M. C. Nevostruyeva, Zhuvam village, Yukamenskiy District, Udmurtia, by Elena Popova.

${ }^{26}$ Recorded from A. D. Sabrekova, Glazov District, Udmurtia, by Elena Popova.

${ }^{27}$ Recorded in Shamardan village, Yukamenskiy District, Udmurtia, by Elena Popova.

${ }^{28}$ Recorded from T. S. Baltacheva, in Tylys village, Yukamenskiy District, Udmurtia, by Elena Popova.

${ }^{29}$ Recorded from D. I. Kalinina, in Gordino village, Balezino District, Udmurtia, by Elena Popova.

${ }^{30}$ Recorded from M. S. Yashkina (Baltacheva), in Tylys village, Yukamenskiy District, Udmurtia, by Elena Popova.

${ }^{31}$ Recorded from V. N. Borisov, in Shamardan village, Yukamenskiy District, Udmurtia, by Elena Popova.

${ }^{32}$ Recorded from M. P. Zyambakhtina, in Turchno village, Yukamenskiy District, Udmurtia, by Elena Popova.

${ }^{33}$ Recorded from N. A. Zyankin, in Filimonovo village, Yukamenskiy District, Udmurtia, by Elena Popova.

${ }^{34}$ Recorded in Ukan village, Yar District, Udmurtia, by Elena Popova.

${ }^{35}$ Recorded in Ukan village, Yar District, Udmurtia, by Elena Popova.

${ }^{36}$ Recorded from A. Tyutina, in Gordino village, Balezino District, Udmurtia, by Elena Popova.

${ }^{37}$ Recorded from N. L. Tyutina, in Gordino village, Balezino District, Udmurtia, by Elena Popova.

${ }^{38}$ Recorded from Z. I. Zhuravl'ova, in Gordino village, Balezino District, Udmurtia, by Elena Popova.

${ }^{39}$ Recorded from A. Tyutina, in Gordino village, Balezino District, Udmurtia, by Elena Popova.

${ }^{40}$ Recorded from Z. I. Zhuravl'ova, in Gordino village, Balezino District, Udmurtia, by Elena Popova. 
Water Bodies in Besserman Mythology and Rituals

\section{References}

Belitser, V. 1958. Ocherki po etnografii komi [Essays on the Ethnography of the Komi]. In: Trudy instituta etnografii. Novaya seriya [Proceedings of the Institute of Ethnography. New Series]. Vol. 14. Moscow: [n.a.].

Biyanova, M. 1946. Istoriya naroda besermyan [History of the Besserman People]. In: Nauchno otraslevoy arkhiv UIIYaL UrO RAN. Rukopisnyy fond. Op. 2N. 1946 g. D. 391 [Scientific Branch Archive of UIIYAL UB RAS. Handwritten Fund. Op. 2H. 1946 D. 391].

Fedotov, M. 1982. Vortsynskiy govor besermyanskogo narechiya [Vortsynsk Dialect of the Besserman Dialect]. In: Obraztsy rechi udmurtskogo yazyka [Specimens of Speech of the Udmurt Language]. Izhevsk: [n.a.], pp. 116-130.

Il'yin, M. 1926. Svadebnyye obychai i obryady u votyakov [Wedding Customs and Ceremonies among the Votyaks]. In: Trudy nauchnogo obshchestva po izucheniyu Votskogo kraya [Proceedings of the Scientific Society for the Study of the Votyak Territory]. Issue 2. Izhevsk, pp. 25-69.

Mashtakova, M. 1970. Polevaya tetrad' etnograficheskoy ekspeditsii v Debesskiy, Balezinskiy, Yarskiy rayony UASSR. 1970 g. [Field Notebook of an Ethnographic Expedition to Debes, Balezino, Yar Districts of the Udmurt ASSR]. In: Nauchno otraslevoy arkhiv UIIYAL UrO RAN. Rukopisnyy fond. Op. 2N. D. 433. Sovmestnaya etnograficheskaya ekspeditsiya UdGU i UdNII [Scientific Branch Archive of UIIYAL UrO RAN. Handwritten Fund. Op. 2H. D. 433. Joint Ethnographic Expedition of UdGU and UdNII].

Minniyakhmetova, T. 2000. Kalendarnyye obryady zakamskikh udmurtov [Calendar Rites of the Eastern (Trans-Kama) Udmurts]. Izhevsk: Udmurtskiy institut istorii, yazyka i literatury Uralskogo otdeleniya Rossiyskoy akademii nauk.

Osokin, I. 1912. Istoricheskiy ocherk pochitaniya prepodobnogo Trifona, Vyatskogo Chudotvortsa ( $† 1612$ goda 8 oktyabrya) [Historical Sketch of the Veneration of the Monk Tryphon, the Vyatka Wonderworker (†1612, October 8)]. In: Trudy Vyatskoy Uchenoy Arkhivnoy Komissii. 1912 god. Vypusk I-II. Posvyashchaetsya pamyati prep. Trifona, Vyatskogo Chudotvortsa, po sluchayu 300-letiya yubileya so dnya ego blazhennoy konchiny [Proceedings of the Vyatka Scientific Archival Commission. 1912 Year. Issue I-II. Dedicated to the Memory of 


\section{Elena Popova}

St Tryphon, the Wonderworker of Vyatka, on the Occasion of the $300^{\text {th }}$ Anniversary of His Blessed Death]. Vyatka, pp. 1-70.

Pervukhin, N. 1888. Eskizy predaniy i byta inorodtsev Glazovskogo uyezda

[Essays about the Legends and the Everyday Life of Non-Russians of the Glazov District]. Eskiz 2: Idolozhertvennyy ritual drevnikh votyakov po ego sledam v rasskazakh starikov i v sovremennykh obryadakh [Essay 2: The Idol-Sacrificial Ritual of the Ancient Votyak in Its Traces in the Stories of Elder People and in Modern Rituals]. Vyatka: Gubernskaya tipografiya.

Popova, E. 2004. Gordinskiy nadgrobnyy kamen' "svyataya mogila" pamyatnik chepetskikh tatar i besermyan [Gordinsky Tombstone "Holy Grave" - a Monument of the Cheptsa Tatars and Bessermans]. In: Kul'tovye pamyatniki Kamsko-Vyatskogo regiona: Materialy $i$ issledovaniya [Cult Monuments of the Kama-Vyatka Region: Materials and Research]. Izhevsk: Udmurtskiy institut istorii, yazyka i literatury Uralskogo otdeleniya Rossiyskoy akademii nauk, pp. 167-177.

Popova, E. 2011. Kul'tovyye pamyatniki i sakral'nyye ob"yekty besermyan [Cult monuments and sacral objects of the Besserman]. Izhevsk: Udmurtskiy institut istorii, yazyka i literatury Uralskogo otdeleniya Rossiyskoy akademii nauk.

Popova, E. 2012. Reki i rodniki v obryadakh i kul'tovoy praktike besermyan [Rivers and Springs in Rituals and Cult Practice of Besserman]. In: Traditsionnaya kul'tura [Traditional Culture] 4, pp. 15-22.

Popova, E. 2014. Talsipühade sanditamised ja maskid bessermanide tänapäevases kalendrikombestikus [Mummery during the Winter Holidays and the Masks in the Contemporary Calendar Tradition]. Mäetagused 57, pp. 91-114.

Pravoslavnyye khramy Udmurtii 2000. Spravochnik-ukazatel' [Orthodox Churches of Udmurtia: Reference Book]. Izhevsk: Izhevsk.

Satrapinskiy, K. 1854. Votyaki i besermyane, prozhivayushchiye v prikhode i sele Ukan Glazovskogo uyezda [The Votyaks and the Bessermans Living in the Parish and Village of Ukan of the Glazov District]. In: Arkhiv Russkogo geograficheskogo obshchestva [Archive of the Russian Geographical Society]. R. 10. Op. 1. D. 48.

Shutova, N. 2004. Svyatilishcha v okrestnostyakh derevni Malyy Dasos: $\mathrm{K}$ voprosu o tipologii i semantike besermyanskikh kul'tovykh mest [Sanctuaries in the Vicinity of the Village of Maly Dasos: On the 
Typology and Semantics of the Besserman Cult Places]. In: Kul'tovyye pamyatniki Kamsko-Vyatskogo regiona: Materialy i issledovaniya [Cult Monuments of the Kama-Vyatka Region: Materials and Research]. Izhevsk: Udmurtskiy institut istorii, yazyka i literatury Uralskogo otdeleniya Rossiyskoy akademii nauk, pp. 154-166.

Steinfeldt, N. 1894. Besermyane. Opyt etnograficheskogo issledovaniya [The Besserman. Experience of Ethnographic Research]. In: Kalendar' i Pamyatnaya knizhka Vyatskoy gubernii na 1895 god [Calendar and memorial book of the Vyatka Governorate for 1895]. Vyatka: Gubernskaya tipografiya, pp. 220-259.

Trifon Vyatskiy 1996. In: Entsiklopediya zemli Vyatskoy [Encyclopedia of the Vyatka Land]. Vol. 6. Znatnyye lyudi [Famous People]. Kirov, pp. 447-448.

Vereshchagin G. 1886. Votyaki Sosnovskogo kraya [The Votyak of the Sosnovka Region]. In: Zapiski Russkogo geograficheskogo obshchestva [Notes of the Russian Geographical Society]. Vol. 14, issue 2. SanktPetersburg.

Vereshchagin G. 1889. Votyaki Sarapul'skogo uyezda Vyatskoy gubernii [The Votyaks of the Sarapul District of the Vyatka Province]. In: Zapiski Russkogo geograficheskogo obshchestva [Notes of the Russian Geographical Society]. Vol. 14, issue 3. Sankt-Petersburg.

Vereshchagin, G. 1998. Staryye obychai i verovaniya votyakov Glazovskogo uyezda [Old Customs and Beliefs of the Votyaks of the Glazov District]. In: Sobraniye sochineniy: Etnograficheskiye ocherki 1 [Collected Essays: Ethnographic Essays 1]. Vol. 6, issue 3, b. 1. Izhevsk: Udmurtskiy institut istorii, yazyka i literatury Uralskogo otdeleniya Rossiyskoy akademii nauk, pp. 206-239.

Vyatskaya eparkhiya 1912. Istoriko-geograficheskoye i statisticheskoye opisaniye (S kartoy Vyatskoy gubernii) [Vyatka Diocese. Historical, Geographical and Statistical Description (With a Map of the Vyatka Governorate)]. Redaktsii Vyatskikh eparkhial'nykh Vedomostey [The Vyatka Diocesan Gazette]. Vyatka: Gubernskaya tipografiya.

Vladykina, T. 1998. Udmurtskiy fol'klor: problemy zhanrovoy evolyutsii $i$ sistematiki [Udmurt Folklore: Problems of Genre Evolution and Systematisation]. Izhevsk: Udmurtskiy institut istorii, yazyka i literatury Uralskogo otdeleniya Rossiyskoy akademii nauk. 


\section{Elena Popova}

Yusupov, G. 1960. Vvedeniye v bulgaro-tatarskuyu epigrafiku [Introduction to the Bulgaro-Tatar Epigraphy]. Moscow-Leningrad: Nauka.

Zorin, N. 1981. Russkaya svad'ba v Srednem Povolzh"ye [Russian Wedding in the Middle Volga Region]. Kazan: Kazansk. Universitet.

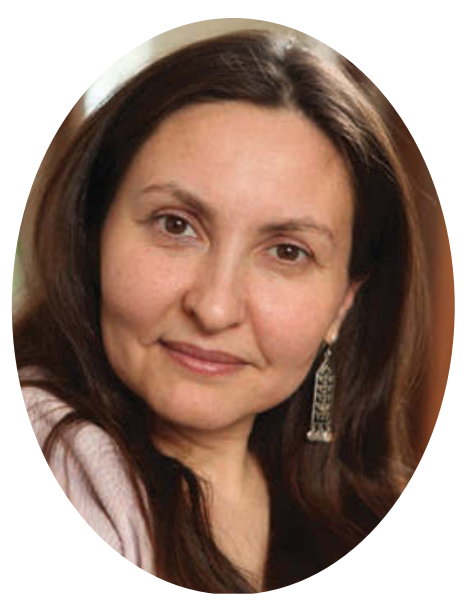

Elena Popova $(\mathrm{PhD})$, is a Senior Research Associate, Udmurt Institute for Research in History, Language and Literature (Udmurt Federal Research Centre of the Ural Branch of the Russian Academy of Sciences), Besserman ethnographer and anthropologist. She has a huge bibliography of research among the Besserman, the Udmurt and other peoples of the Volga-Kama region. Her interests are wide, from spiritual to material culture, from traditional rituals to the most contemporary phenomena of modern world.

e-mail: elvpopova@yandex.ru 